\title{
Modeling the Impact of Riparian Vegetation on Flow Structure and Bed Sediment Distribution in Rivers
}

\author{
Mabrouka Morri ${ }^{1}$, Amel Soualmia ${ }^{2}$ \\ ${ }^{1}$ Regional Commissariat for Agricultural Development of Kebili; Salah Ben Youssef Street, 4200 Kebili, \\ Tunisia, e-mail: morri.mabrouka@yahoo.fr (corresponding author), ${ }^{2}$ Laboratory of Water Sciences and \\ Technology; 43 Street of Charles Nicolle 1028 Tunisia, e-mail: lmmimllm@yahoo.fr
}

(Received June 03 2019; revised April 21, 2020)

\begin{abstract}
The effect of instream vegetation growth has largely been ignored by hydrological and geomorphological research in river environments, which focused instead on the function of riparian vegetation as a regulator of bank stability or as a buffer for dissolved and particulate matter entering the channel from the hillside. However, in many lowland streams, instream vegetation can be very intensive, resulting in high biomass levels during the growing season. Instream plants have a significant influence on the dynamics of flow, sediment, and nutrients. Plant growth can cause increased frictional resistance to flow and can have a short-to medium-term effects on the geomorphology of the channel. Additionally, plant development influences the velocity of river flow, affects sedimentation dynamics and increases flood risk. To achieve a balance between flooding and ecological management of rivers in the presence of vegetation, a reliable method is required to predict the resistance of channels. In the current study, a two-dimensional hydrodynamic and morphodynamic model is developed and applied using a new scaling expression of shear stress based on vegetation characteristics. These first attempts at field simulations showed qualitatively acceptable results and demonstrated the effectiveness of the model in predicting hydraulic parameters in the presence of vegetation. This model is useful in predicting the effect of vegetation on stream flow and river morphology, as well as in managing flood hazards and stream ecology.
\end{abstract}

Key words: rivers, sediment, flood, vegetation, model

\section{Introduction}

Over recent decades, watercourses have been exposed to major threats due to human activities that have modified their structure. Dikes were constructed to avoid flooding, large dams were built, and large quantities of sediment were extracted. Such actions caused certain problems, such as incision of the main channel and lower water levels.

(C) 2019 Institute of Hydro-Engineering of the Polish Academy of Sciences. This is an open access article licensed under the Creative Commons Attribution-NonCommercial-NoDerivs License (http://creativecommons.org/licenses/by-nc-nd/3.0/). 
In its turn, the incision of the bed in some parts of the river and the lack of solids transport led to the development of many vegetated islands (Rodrigues et al 2006).

The growth of vegetation on a narrow bed or in floodplains may have a major impact on the river's total discharge capacity. The development of vegetation in an open channel usually interferes with the normal functioning of streams, decreases flow velocity, and increases shear stress, thus increasing flood risks (Nepf 1999, Huthoff et al 2007, Liu and Shen 2008, Samani and Mazaheri 2009, Wu and He 2009).

Many rivers, such as the Medjerda river in Tunisia, are affected by the problem of vegetation growth. Vegetation development in this river was considered an important factor in the proliferation of floods, which cause significant material damage and pose a serious risk to the population, such as the floods of 1973 and 2003 (Zahar et al 2008, Jaziri 2009, Hammami 2010). In France, the river Isere shows also rapid colonization by woody vegetation (Allain Jégou 2002, Rodrigues et al 2006, Jourdain 2017). Consequently, some earlier studies centered on the effect of vegetation resistance in river flows, and numerous simulations of flow through vegetation have been produced to clarify the relationship between flow, vegetation, and sediment transport (Tsujimoto et al 1993, Klopstra et al 1997, Nepf and Vivoni 2000, Lopez and Garcia 2002, Ghisalberti and Nepf 2002, Righetti and Armanini 2002, Carollo et al 2005, Jarvela 2005, Baptist et al. 2007 Huthoff et al 2007, Augustijn et al 2008, Kubrak et al 2008).

In the current study, a two-dimensional hydrodynamic and morphodynamic model is developed using a new concept of shear stress scaling based on vegetation characteristics. This model is applied to two stretches of rivers influenced by vegetation growth to predict the impact of vegetation on stream behavior and river morphology.

\section{Model Description}

Nowadays, most natural disasters and economic damages are related to flood threats, which are a fundamental part of river dynamics. Therefore, the controlling of floods and the understanding of river dynamics are essential to reduce the disastrous consequences of floods. Hydraulic models are commonly used for predicting risks related to water levels and for identifying vulnerable areas to protect the population from flood damage. The most common are one- or two-dimensional models (Horritta and Batels 1999). One-dimensional models are widely used to describe the in-channel flow without taking into account the wide horizontal distribution that occurs during flooding events. To simulate flooding processes and investigate the hydrodynamics of rivers, two-dimensional models have to be used instead (Villaret and Hervouet 2006). In this article, we use the Telemac-Mascaret modeling system to simulate free-surface and sediment transport using the finite element method and an internal coupling between the hydrodynamic model Telemac $2 \mathrm{D}$ and the morphodynamic model Sisyphe. 


\subsection{Telemac 2D Hydraulic Model}

Telemac $2 \mathrm{D}$ is a widely used software for open source engineering. It is particularly well adapted to study water movements in shallow aquatic domains: coastal areas, estuaries, rivers, and lakes. Telemac 2D uses a finite element approach to solve shallow water flow equations in two horizontal space dimensions over non-structured grids composed of triangles. Such equations describe the conservation of water mass (the continuity equation) and momentum in both horizontal directions of space (dynamic equations) in each computational domain node. The main results of the simulations are the depth of water and the average velocity over depth for each mesh node (Villaret and Hervouet 2006). It takes into account various physical phenomena, such as bed friction, the intertidal wetting region, turbulence, and the influence of the Coriolis force.

Telemac 2D is used in many fields of application. In the maritime field, it is used in studies of the effect of submersible breakwaters or dredging works, dam breaks, floods, transport of dissipating and non-dissipating tracers.

In Telemac 2D, the following equations are simultaneously defined:

- Continuity equation:

$$
\frac{\partial h}{\partial t}+\vec{u} \vec{\nabla}(h)+h \operatorname{div}(\vec{u})=S_{h}
$$

- Momentum equations:

- Momentum along $x$ :

$$
\frac{\partial u}{\partial t}+\vec{u} \vec{\nabla}(u)=-g \frac{\partial Z}{\partial x}+S_{x}+\frac{1}{h} \operatorname{div}\left(h v_{t} \vec{\nabla} u\right),
$$

- Momentum along $y$ :

$$
\frac{\partial v}{\partial t}+\vec{u} \vec{\nabla}(v)=-g \frac{\partial Z}{\partial y}+S_{y}+\frac{1}{h} \operatorname{div}\left(h v_{t} \vec{\nabla} v\right),
$$

- Tracer conservation:

$$
\frac{\partial T}{\partial t}+\vec{u} \vec{\nabla}(t)=S_{T}+\frac{1}{h} \operatorname{div}\left(h v_{T} \vec{\nabla} T\right),
$$

where:

$$
\begin{array}{ll}
h & - \text { depth of water }(\mathrm{m}), \\
u, v & - \text { velocity components }(\mathrm{m} / \mathrm{s}), \\
T & - \text { passive (non-buoyant) tracer }(\mathrm{g} / \mathrm{l}), \\
g & - \text { gravity acceleration }\left(\mathrm{m} / \mathrm{s}^{2}\right), \\
v_{t}, v_{T}-\text { momentum and tracer diffusion coefficients }\left(\mathrm{m}^{2} / \mathrm{s}\right), \\
Z & - \text { free surface elevation }(\mathrm{m}), \\
t & - \text { time }(\mathrm{s}),
\end{array}
$$


$x, y-$ horizontal space coordinates $(\mathrm{m})$,

$S_{h} \quad-$ source or sink of fluid $(\mathrm{m} / \mathrm{s})$,

$S_{x}, S_{y}-$ source or sink terms in dynamic equations $\left(\mathrm{m} / \mathrm{s}^{2}\right)$,

$S_{T} \quad-$ source or sink of tracer $(\mathrm{g} / \mathrm{l} / \mathrm{s})$.

$T, h, u$ and $v$ are the unknowns. $S_{x}$ and $S_{y}\left(\mathrm{~m} / \mathrm{s}^{2}\right)$ are source terms representing the wind, the Coriolis force, bottom friction, and a source or a sink of momentum within the domain.

The different terms of these equations are determined in one or more stages (in the case of advection, by the properties method):

- Advection of $h, u, v$ and $T$;

- Propagation, diffusion, and source terms of the dynamic equation;

- Diffusion and source terms of the tracer transport equation.

$T, h, u$ and $v$ may be advected separately, and then it is possible to solve the tracer advection and diffusion equation using a fixed advection velocity field. The turbulent viscosity may be given by the user or determined by a model simulating the transport of turbulent quantities $k$ (turbulent kinetic energy) and Epsilon (turbulent dissipation).

Telemac 2D can be coupled with a sediment transport model and can take into account different phenomena, such as friction on the bed, using the quadratic friction coefficient $C_{d}$. It is possible to choose among several laws of friction, such as Chezy's, Stickler's, Manning's, and Nikuradse's. Such classical relationships are derived to define the bottom and side walls without taking into account the drag related to the vegetation, and then a new model of roughness is required to incorporate vegetation effects into hydrodynamic computations based on vegetation characteristics.

The vegetation parameters were incorporated into the Telemac $2 \mathrm{D}$ hydrodynamic software by modeling a new roughness law based on the approach proposed by Huthoff et al (2007). This model is based on a two-layer approach in which flow characteristics are attributed to two separate layers and the vegetation is treated as homogenous field of identical cylindrical stems This relationship is simple in form and shows excellent agreement with experimental results (Morri et al 2016).

The following figure illustrates the velocity profile in the case of submerged shallow vegetation.

The average velocity in the vegetation layer $\left(U_{1}\right)$ is based on the momentum equation resolution.

The average velocity in the upper layer $\left(U_{2}\right)$ is calculated based on the assumption of scaling and experimental calibration.

The average velocity of the whole bulk flow $(U)$ is calculated by combining the mean velocity in the layer of vegetation with that in the upper layer. For shallow vegetation, $1<h / h_{p} \ll 5$, the mean velocity is given by the following equation:

$$
U=\sqrt{\frac{2 g i}{C_{D} m D}}\left(\sqrt{\frac{h_{p}}{h}}+\frac{h-h_{p}}{h}\left(\frac{h-h_{p}}{s}\right)^{\frac{2}{3}\left(1-\left(\frac{h}{h_{p}}\right)^{-5}\right)}\right),
$$




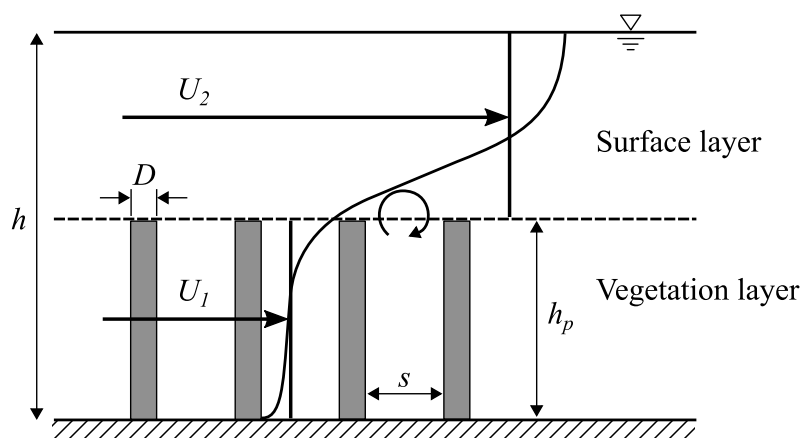

Fig. 1. Velocity profile in the case of shallow submerged vegetation

where:

$U-$ mean velocity $(\mathrm{m} / \mathrm{s})$,

$h-$ water depth (m),

$h_{p}-$ vegetation height $(\mathrm{m})$,

$g-$ gravity acceleration $\left(\mathrm{m} / \mathrm{s}^{2}\right)$,

$C_{D}-$ vegetation drag coefficient,

$m-$ density of vegetation $\left(\mathrm{m}^{-2}\right)$,

$D$ - diameter of plant stems (m),

$s \quad-\quad$ separation between individual resistance elements (m),

$i \quad-$ energy gradient.

Based on (Eq. 5), we determine the quadratic friction coefficient $C_{d}$ :

$$
C_{d}=\frac{C_{D} m D}{\left(\sqrt{\frac{h_{p}}{h}}+\frac{h-h_{p}}{h}\left(\frac{h-h_{p}}{s}\right)^{\frac{2}{3}\left(1-\left(\frac{h}{h_{p}}\right)^{-5}\right)}\right)^{2}} .
$$

This relationship is incorporated into the TELEMAC 2D model using the FORTRAN programming language, and thus complements the classical model with a new roughness model which takes into account the impact of vegetation. This hydrodynamic model can be combined with a morphodynamic model for predicting bed evolution in the presence of vegetation and for calculating sediment transport rates, such as the Sisyphe model.

\subsection{Sisyphe 2D Sediment Transport Model}

Sisyphe is a horizontal, two-dimensional model used to estimate sediment transport and bed evolution. It can be used to model complex morphodynamic processes in different settings, such as coastal areas, rivers, lakes, and estuaries, for different flow levels, sediment size classes, and modes of sediment transport. The main hydrodynamic variables calculated by Telemac $2 \mathrm{D}$ are input into Sisyphe to calculate the bed 
load sediment transport choosing among seven transport formulae, including those by Meyer-Peter and Muller, Engelund-Hansen, Van Rijn and Einstein-Brown, and to calculate the suspended load by solving the advection-diffusion equation. The bottom evolution is calculated using the Exner equation (Villaret et al 2013).

The coupling between the Telemac 2D hydrodynamic model and the Sisyphe sedimentary transport model at each time step constitutes the "hydro-sedimentary" calculation. In this case, the hydrodynamic calculation is continuous and uses bathymetry modified by solids transport, whereas the sedimentary calculation is carried out using adjusted hydraulic variables.

We chose Van Rijn's method for estimating the transport of sediments for the following reasons:

- Van Rijn's relationship is valid for a wide range of particle diameters, from 0.1 to $2 \mathrm{~mm}$.

- This relationship is based on the decomposition of the shear stress into two components: a shear component determines the bed-load transport, and the other component is used to calculate the suspension transport.

- Van Rijn's relationship makes it possible to calculate the equilibrium suspensions profile.

- The numerical setting of this formula results from a large data compilation.

Van Rijn's bed load transport relationship is given by the following equation (Van Rijn 1984, 1993):

$$
Q_{b}=0.053 \sqrt{g \frac{\rho_{s}-\rho}{\rho}} D_{50}^{3} T_{n}^{2.1}\left(d^{*}\right)^{-0.3},
$$

where:

$Q_{b}-$ bed-load transport per unit width $\left(\mathrm{m}^{2} / \mathrm{s}\right)$

$\rho \quad-\quad$ water density $\left(\mathrm{kg} / \mathrm{m}^{3}\right)$,

$\rho_{s}-$ sediment density $\left(\mathrm{kg} / \mathrm{m}^{3}\right)$,

$D_{50}-$ sediment particle size $(\mathrm{m})$,

$d^{*}-$ dimensionless particle size $(\mathrm{m})$,

$T_{n}-$ transport parameter calculated by:

$$
T_{n}=\frac{\theta^{\prime}-\theta_{c}}{\theta_{c}},
$$

where $\theta_{c}$ is the critical Shields parameter and $\theta^{\prime}$ is the non-dimensional bottom friction Shields parameter.

For the suspended sediment rate, the following equation was proposed by Van Rijn (Van Rijn 1984, 1993):

$$
C_{e q}=0.015 \frac{D_{50}}{h_{p}} \frac{T_{n}^{1.5}}{\left(d^{*}\right)^{0.3}},
$$

$C_{e q}$ is concentration at equilibrium. 


\section{Model Prediction of the Vegetation Effect on Flow Resistance and Flood Stage: The Case of the Medjerda River}

\subsection{Study Area Description}

The Medjerda is a perennial river that extends from across the Algerian border to the Utica Gulf in Tunisia. The river has a length of $484 \mathrm{~km}$ and is characterized by a sub-humid to semi-arid climate with an average annual rainfall in the watershed of $480 \mathrm{~mm} /$ year (Zahar et al 2008). The Medjerda watershed covers a total area of 23700 $\mathrm{km}^{2}$, including $7600 \mathrm{~km}^{2}$ in Algeria (Fig. 2). It is divided into the high, middle and lower sub-watersheds.

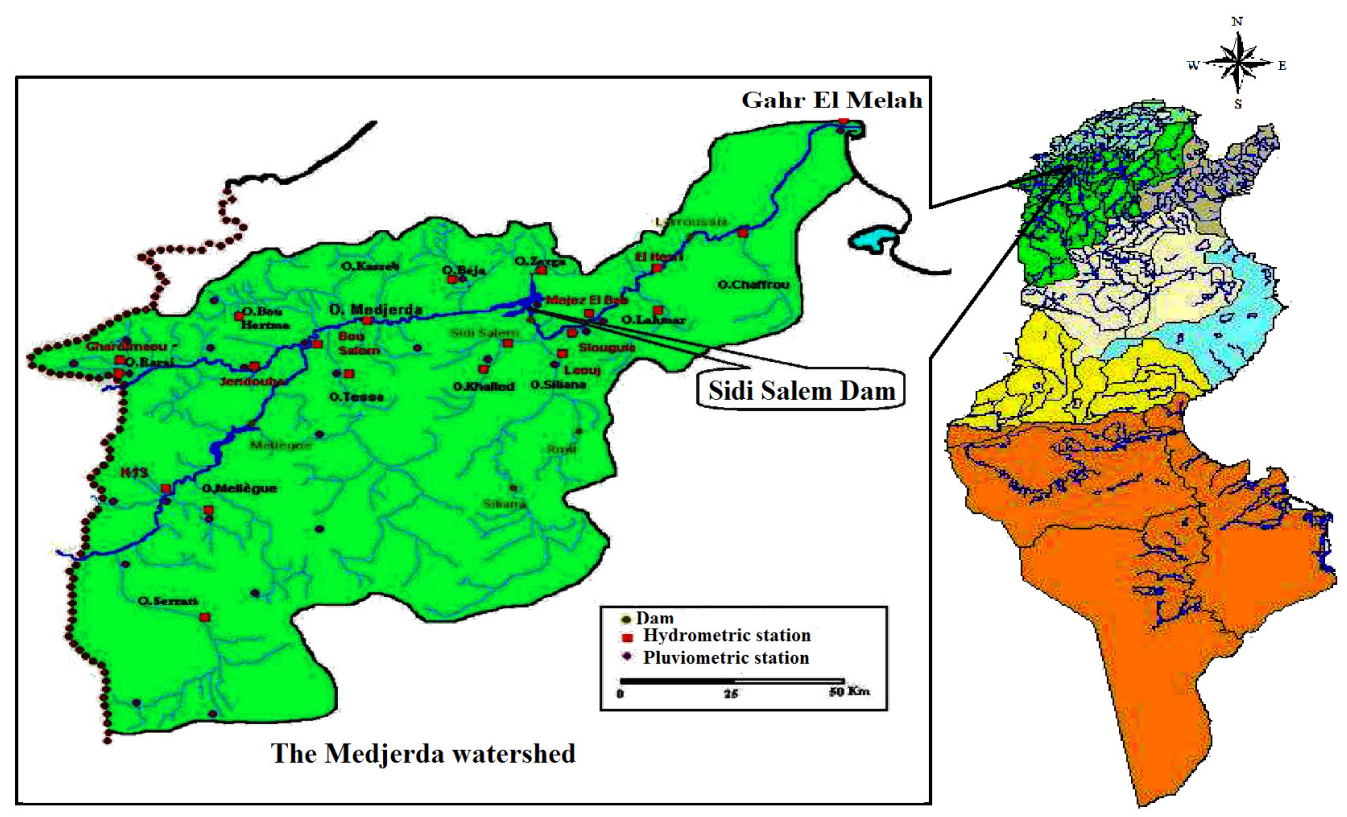

Fig. 2. The Medjerda river location

Many hydraulic projects have been constructed in this watershed since 1945 to mitigate floods that caused significant material damage and posed a significant danger to the population. However, the construction of these reservoirs has led to the natural deterioration of the Medjerda by limiting cross-sections as a result of sediment deposition and vegetation growth downstream of the dams (Zahar et al 2008, Ben Mammou and Louati 2007, Fehri 2014).

In this study, we are interested in a $19 \mathrm{~km}$ section of the Medjerda located downstream of the Sidi Salem dam between Slouguia and Madjez El Bab. We are going to simulate different hydraulic parameters during a flood and test the capacity of the model to predict the hydrodynamic behavior of the river in the presence of vegetation. 


\subsection{Implementation of the Hydraulic Model}

To evaluate the capacity of the model to predict the hydrodynamic behavior of the river in the presence of vegetation, we analyzed the flood of February 2012 (from 23 February 2012 to 3 March 2012). Then, we collected topographical and bathymetric data required by the Telemac $2 \mathrm{D}$ hydrodynamic model to define river geometry. We used topographic maps on a scale of $1: 25000$ and cross-sections measured during a topographic campaign in 2003, since measured cross-sections for 2012 were not available. A one-dimensional model (HEC-RAS) was used to interpolate cross-sections and to produce a detailed definition of the river bed (Fig. 3).

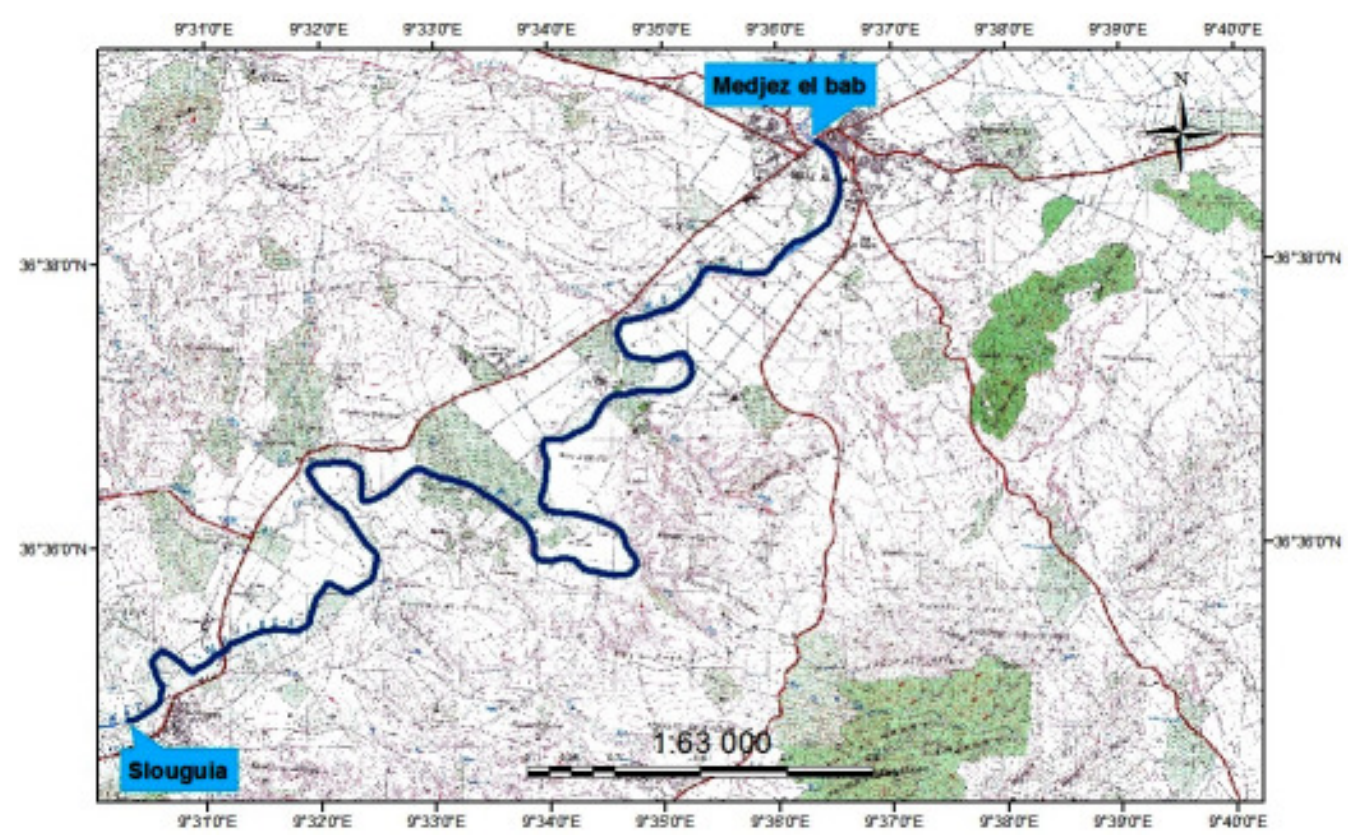

Fig. 3. Location of the river section between Slouguia and Medjez El Bab

The area mesh was developed by the Blue Kenue model using the finite element method. A difficulty in mesh construction is to select an optimal mesh number that ensures the best representation of the study field. Different grids were obtained by changing mesh density and the field of study to provide an accurate representation.

Variable mesh size was used to refine the mesh near the riverbed more than at the edges of the study area. The grid shown in Fig. 4 consisted of 23762 nodes and 47200 elements.

The description of boundary conditions in the study area is based on hydraulic data available for the flood of 2012. The observed flow hydrograph was used as the upstream condition. On the downstream side, we used the rating curve $h(Q)$ for the flood of 2012. 


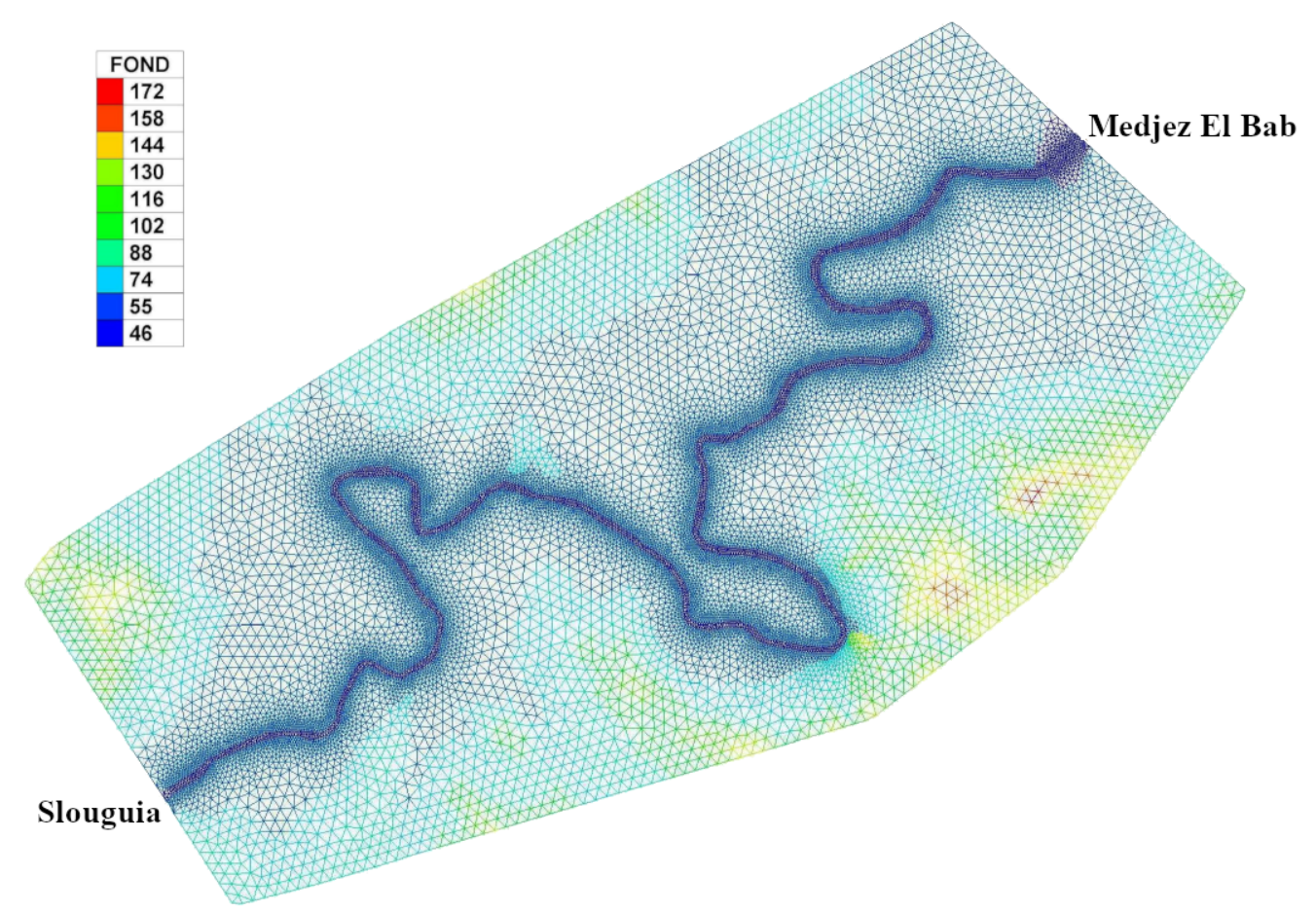

Fig. 4. Meshing and bathymetry of the Medjerda River between Slouguia and the Medjez El Bab station

The calibration of the model was based on change in the vegetation drag coefficient $\left(C_{D}\right)$. This parameter has a significant impact on the variation of river water levels. Several simulation experiments were performed by adjusting the vegetation drag coefficient and comparing expected water depth profiles with those measured during the flood of 2012 and using the Root-Mean Square Error (RMSE).

For a vegetation drag coefficient $C_{D}$ of 1 , this model showed the smallest error in estimating the water profile for the flood of 2012 with a Root-Mean Square Error (RMSE) of 0.01 (Fig. 5). In estimating the hydrodynamic parameter in the presence of vegetation, we retained this value to assess the effectiveness of this model.

\subsection{Model Testing and Evaluation}

\subsubsection{Flow Discharge Prediction}

The flow discharge measured during the flood of 2012 was used to validate the new model's ability to predict the flood hydrograph in the presence of vegetation. The relation between hydrographs simulated and observed during the flood of February 2012 shows a reasonable agreement (Fig. 6).

The overall form of flooding is, in general, good. It is noted that the predicted flood peaks occur on the same dates as the observed flood peaks, which shows that 


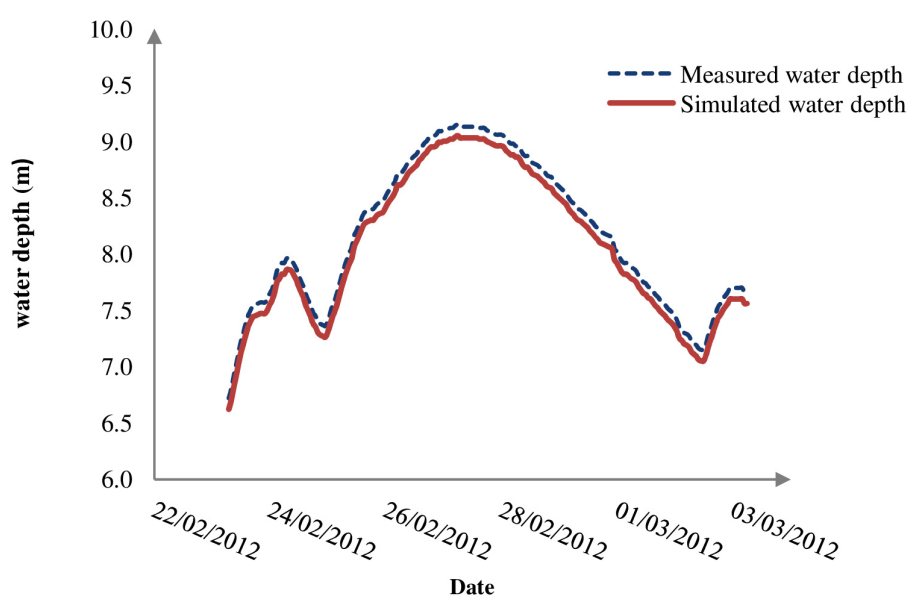

Fig. 5. Measured and simulated water levels at the Slouguia station during the flood of February 2012 for vegetation drag coefficient $C_{D}=1$

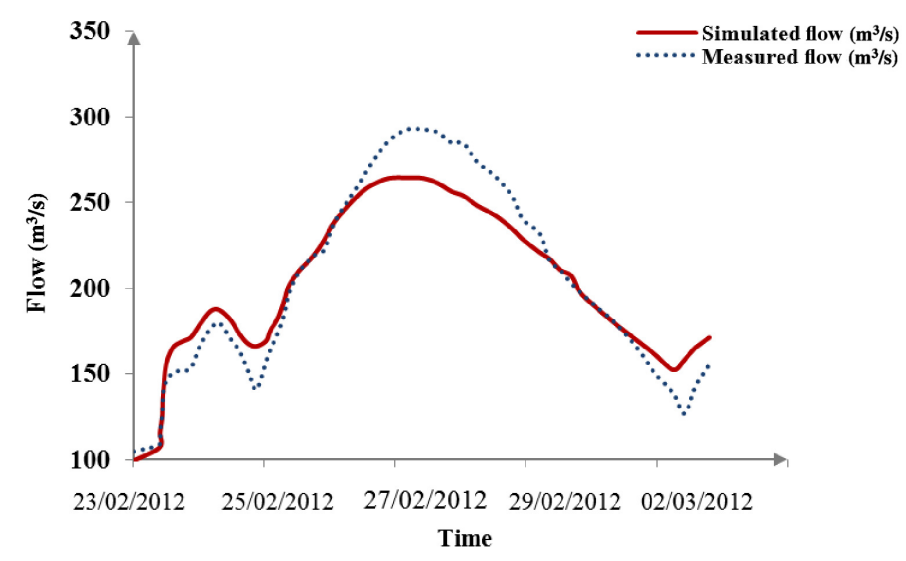

Fig. 6. Comparison of flow hydrographs simulated and measured during the flood of February 2012

the time error for propagation is almost negligible. The average flow rate observed is about $192 \mathrm{~m}^{3} / \mathrm{s}$, and the simulated flow rate is about $193 \mathrm{~m}^{3} / \mathrm{s}$. The maximum flow observed during the flood of 2012 is about $300 \mathrm{~m}^{3} / \mathrm{s}$, whereas the flow rate estimated by the model is about $265 \mathrm{~m}^{3} / \mathrm{s}$, which is smaller by about $9 \%$. The discrepancy between calculated and observed results is determined using the criteria of deviation (the coefficient of determination $\mathrm{R}^{2}$ and the NASH criterion). Fig. 7 shows a high coefficient of determination $\mathrm{R}^{2}$ value (about 96 percent), which indicates the success of the model in predicting the flow rate during a flood. The estimation of the NASH criterion also shows the usefulness of this model, with a value close to 1 of about 0.92 . The small disparity between the measured and simulated values may be explained by the lack of measured cross-section data for the flood of February 2012. 


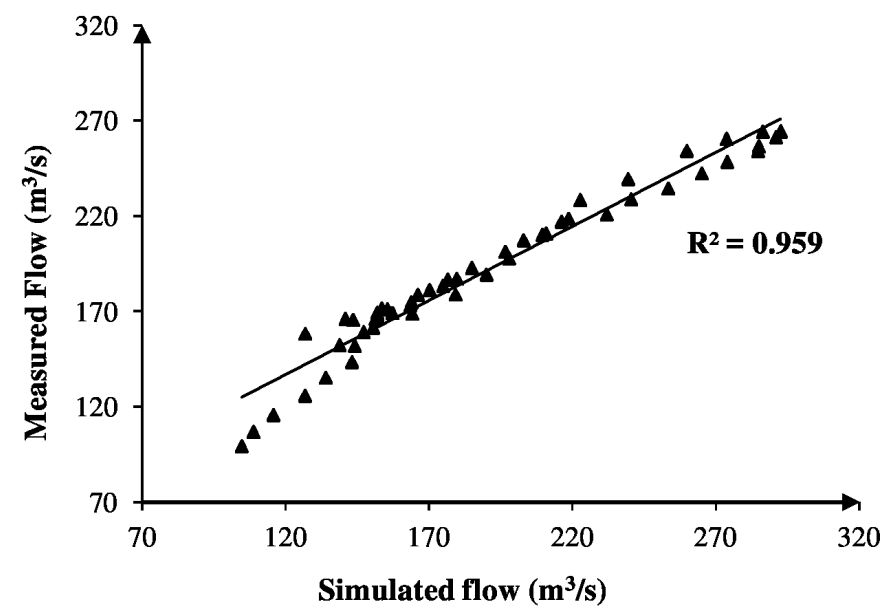

Fig. 7. Comparison of measured and simulated flow discharge during the flood of February 2012

\subsubsection{Water Level Prediction}

The vegetation that develops on the river bed, on the banks of the river, and in secondary channels restricts the initial flow section and disrupts the natural functioning of the watercourse. It decreases velocity, which increases the water level and flood risk. By comparing two simulations, one from the new model and the other from the one-dimensional model Mike 11 (Fig. 8), we try to determine the capacity of the former model to estimate the water level during a flood in the presence of vegetation.

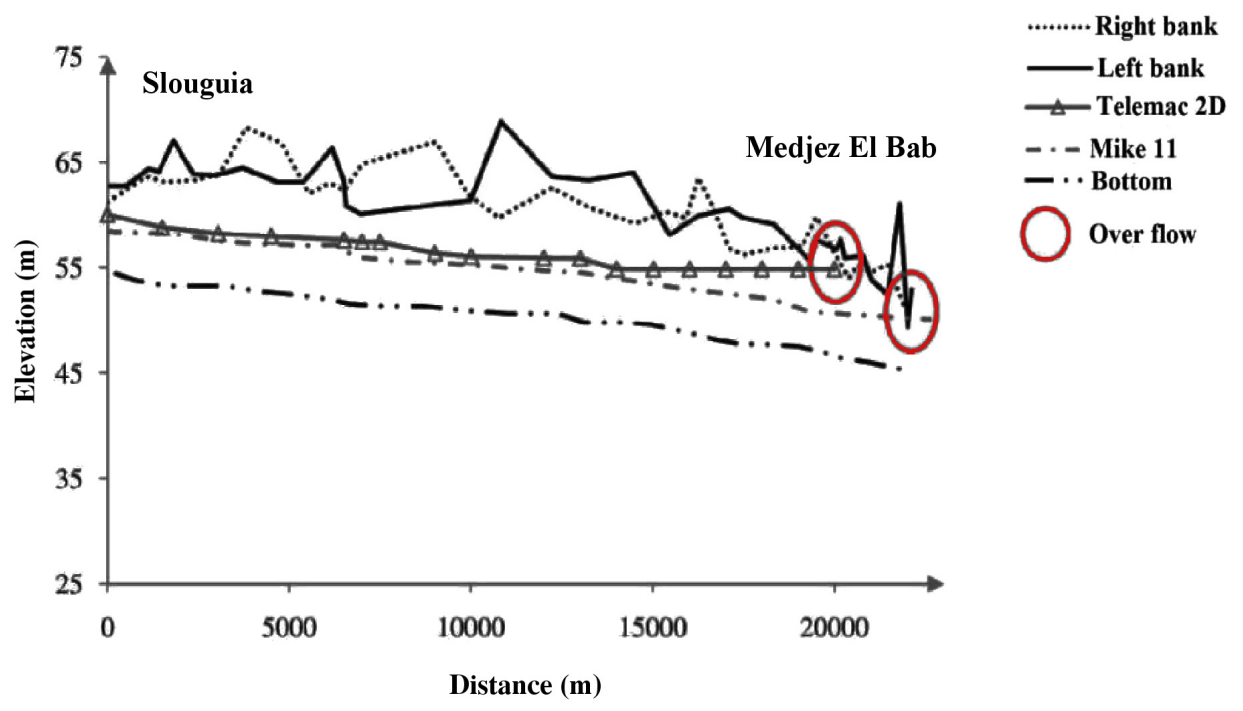

Fig. 8. Predictions of water levels along the Medjerda river during the flood of February 2012 
There is very little variation in water levels simulated by the two models. A minor downstream change occurs at the Medjez El Bab station. The results obtained by these models also indicate that the overflowing section is located in Medjez El Bab. This town was greatly affected during the flood of 2012.

This comparison demonstrates the potential of the present model for predicting the water level and proves the validity of the model, which very useful in setting safety standards for flood protection.

Below, we present a scenario of vegetation removal to explain its overflow effect (Fig. 9). Vegetation growth in the river section between Slouguia and Medjez El Bab causes the water level to rise. The maximum water level in the presence of vegetation is roughly $65 \mathrm{~m}$, while the maximum water level after the removal of vegetation reaches $64 \mathrm{~m}$. Thus, the presence of vegetation raises the water level by around $1 \mathrm{me}-$ ter. This simulation shows the efficacy of removing vegetation from the bottom and banks in mitigating flood risks and shows that the model can correctly predict the effect of vegetation on the flow.

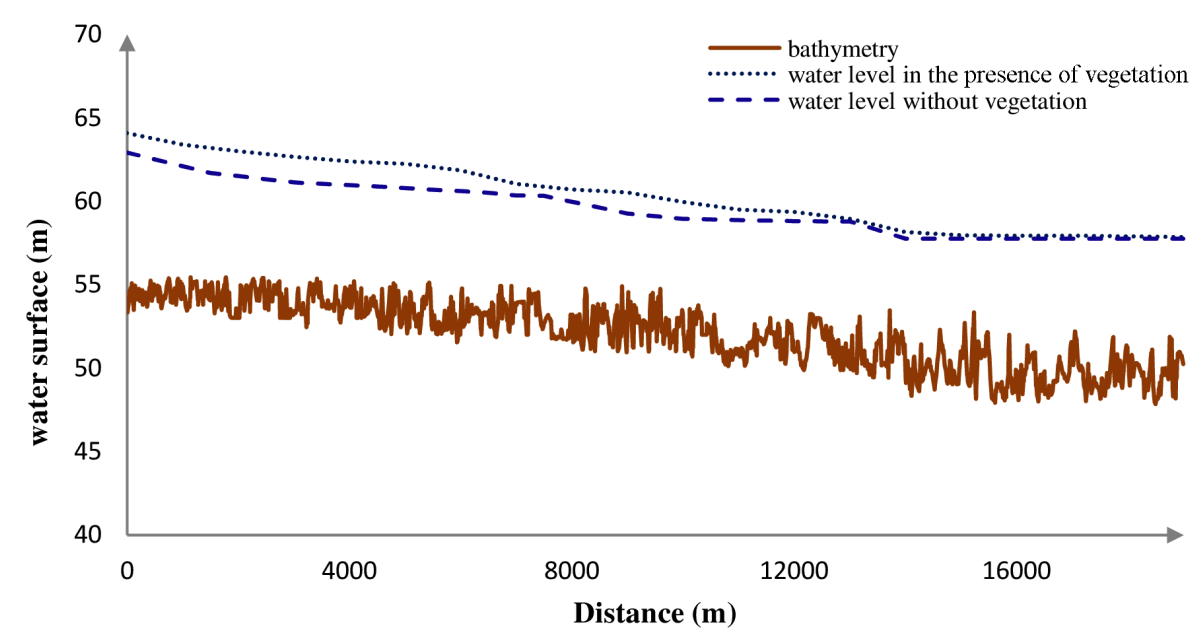

Fig. 9. Comparison of simulated water level profiles along the Medjerda River with vegetation and without vegetation between Slouguia and Medjez El Bab

\section{Model Prediction of the Vegetation Effect on Sediment Transport Processes: The Case of the Isere River}

\subsection{Study Area Description}

The Isere, a river in the Northern Alps, is one of the Rhone's main tributaries. Its watershed covers a total area of $11800 \mathrm{~km}^{2}$. This river shows a rapid colonization by woody vegetation which affects stream process and changes the river hydraulic conditions, the morphology, as well as the local fine sediment deposition (Dumas 
2008, Allain Jégou 2010). The studied reach of the river, situated in the Grésivaudan between station P295 and the Brignoud Bridge (Fig. 10), is $1 \mathrm{~km}$ long and $100 \mathrm{~m}$ wide. The modeling data come from Allain Jegou's experimental measurements during and after the flood of October 2000. Sediment distribution and deposit granulometry were determined on a vegetated island after each submersion. The diameter of deposit sediments ranged from $260 \mu \mathrm{m}$ to $60 \mu \mathrm{m}$, and the flow velocity was about $1 \mathrm{~m} / \mathrm{s}$.

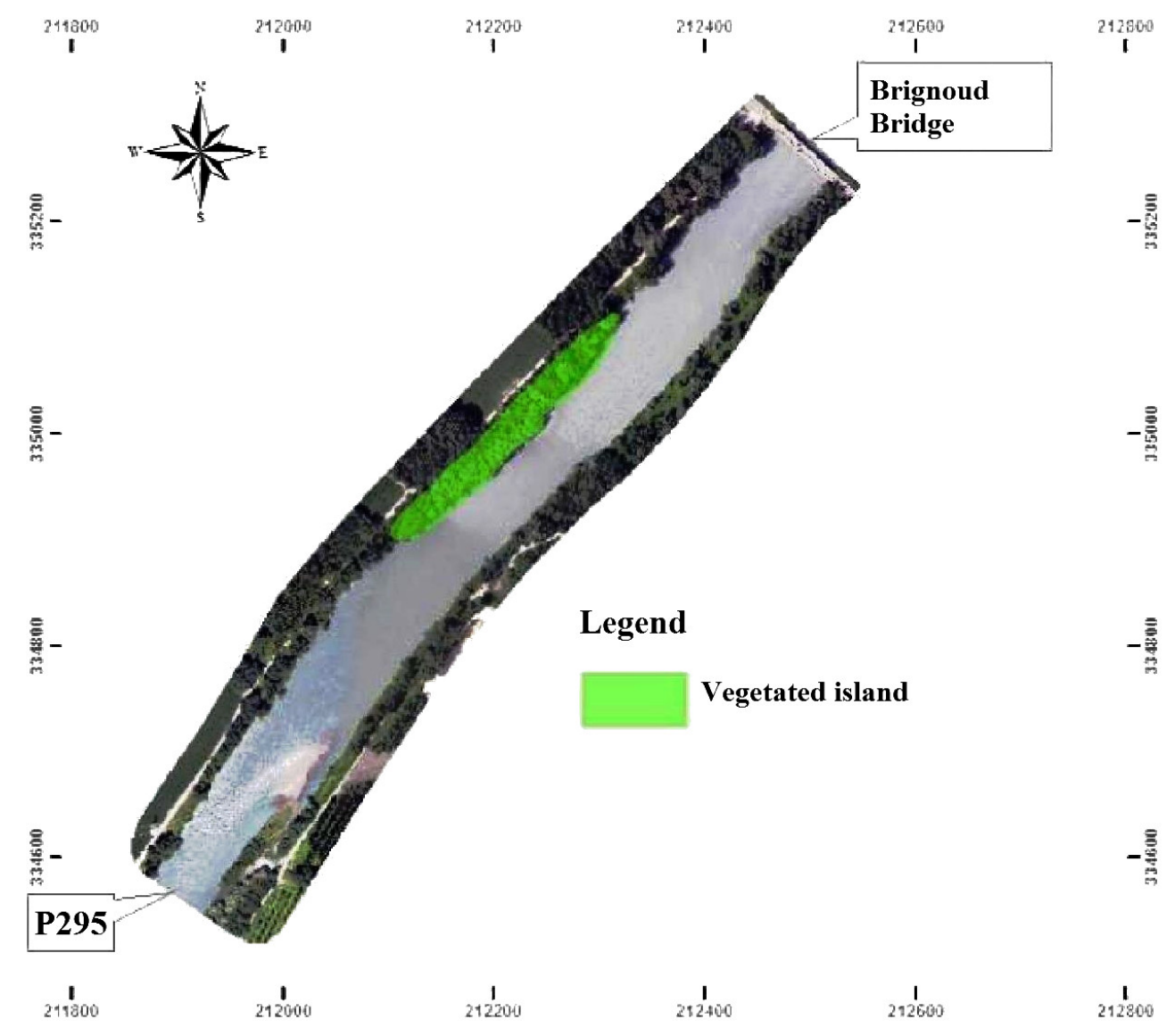

Fig. 10. The studied section in the Isere river

Before modeling, the structure of the region must be represented using various mesh sizes, and boundary conditions must be identified. A hydrograph of the flood in October 2000 was applied at the upstream limit, and the calculated rating curve was set at the downstream limit. The purpose of this simulation was to evaluate the model's capacity to predict the effect of vegetation on hydraulic parameters and the distribution of sediments in the examined section. Two scenarios were considered: the first without a vegetated island and the second with a vegetated island in the Isere channel. 


\subsection{Prediction of Vegetation Effect on Flow Velocity}

The vegetation effect on flow velocity can be estimated by comparing flow velocities before and after the removal of vegetation (Fig. 11).

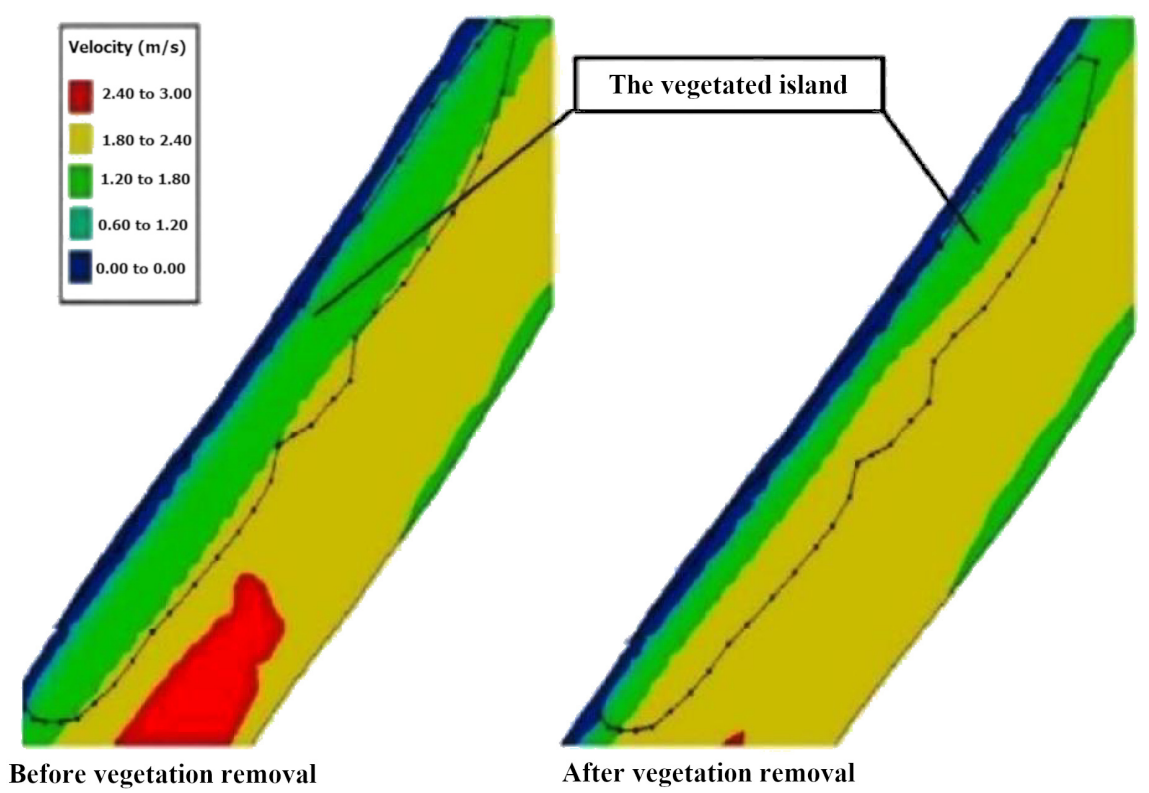

Fig. 11. Velocity fields before and after the removal of vegetation from the island and the main bed of the Isere river between the Brignoud Bridge and station P295

Before the removal of vegetation, the flow velocity in the vegetated region is low, ranging from 0 to $1.8 \mathrm{~m} / \mathrm{s}$, and it is close to the measured velocity. Nevertheless, the flow velocity in the main bed of the studied section is greater than that velocity and reaches a maximum of $3 \mathrm{~m} / \mathrm{s}$.

After vegetation removal, flow velocity in the vegetated area increases to $2.4 \mathrm{~m} / \mathrm{s}$, while flow velocity in the main bed decreases. This comparison demonstrates the capacity of the model to reproduce the actual situation and to predict the effect of vegetation on velocity.

\subsection{Prediction of Vegetation Effect on Sediment Distribution}

The removal of riparian vegetation has an impact not only on the velocity of flow, but also on the distribution of sediments. The following figure shows the distribution of sediments before and after the removal of vegetation according to the new model.

Fine sediments, with a diameter ranging from $0.0001 \mathrm{~m}$ to $0.003 \mathrm{~m}$, are deposited in the vegetated area. These values are identical to those measured. The diameter of sediment on the main bed is around $0.04 \mathrm{~m}$. After the removal of vegetation, we note a homogenization of the diameters. The diameter of sediment on the island drops to 


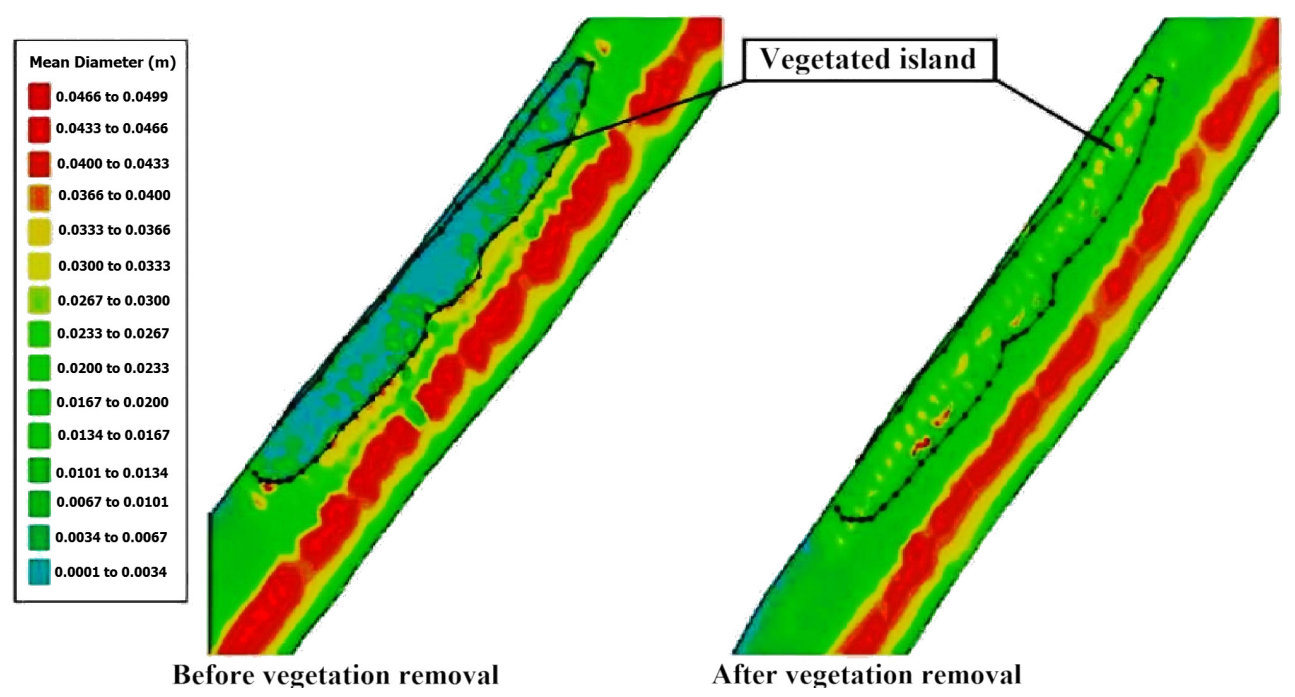

Fig. 12. Sediment distribution before and after the removal of vegetation from the main bed of the Isere river

around $0.02 \mathrm{~m}$. The diameters on the main bed, decrease as well. The deposition of sediments in the vegetated zone is associated with a decrease in the shear stress due to the drag force of the vegetation. This scenario demonstrates the model's success in predicting the velocity effect on the distribution of sediment during a flood.

\section{Conclusions}

A depth-averaged two-dimensional numerical model was developed to simulate flow, sediment transport, and morphological changes in the river channel in the presence of vegetation. The hydraulic resistance produced by streamed vegetation is provided by an adapted bottom friction coefficient based on vegetation characteristics and incorporated in the Telemac 2D hydrodynamic model using assumptions and a numerical scheme necessary to make a formulation well adapted to the modeling of the flow and sedimentary transport. This model was applied to specific cases of rivers affected by vegetation growth: a $20 \mathrm{~km}$ section of the Medjerda river in Tunisia and a $1 \mathrm{~km}$ stretch of the Isere in France. Using deviation criteria, the model was compared with measured data. The flow discharge was predicted very accurately, with a high determination coefficient $\mathrm{R}^{2}(96 \%)$ and with a NASH criterion close to 1 . The new programmed roughness relationship was also successful in predicting the water level and velocity. The present model, coupled with the sedimentary model Sisyphe, was also tested in estimating the distribution of sediments and morphological changes in the presence of vegetation, demonstrating its capacity to reproduce the real situation, and this is very useful in setting safety standards for flood protection. Nevertheless, further simulations have to be made with more accurate field measurements in order to extend the applicability of the model. 


\section{References}

Arellano D., Stark T. D. (2000) Importance of three-dimensional slope stability analysis in practice, [In:] Griffiths et al (Eds.), Slope Stability 2000, GSP 101, Reston, ASCE, 18-32.

Allain Jégou C. (2002) Vegetation, flow and sediment transport interactions in rivers beds: Study of the Isere in Gresivaudan (Relations végétation, écoulement-transport solide dans le lit des rivières, étude de l'Isère dans le Grésivaudan), PhD Thesis, National Polytechnic Institute of Grenoble, France.

Augustijn D. C. M., Huthoff F., van Velzen E. H. (2008) Comparison of vegetation roughness descriptions, Proceedings of River Flow - Fourth International Conference on Fluvial Hydraulics, 3-5 September 2008, Çeşme, Izmir, Turkey, 343-350.

Baptist M. J., Babovic V., Rodríguez Uthurburu J., Keijzer M., Uittenbogaard R. E., Mynett, A.Verwey A. (2007) On inducing equations for vegetation resistance, Journal of Hydraulic Research, 45, 435-445, https://doi.org/10.1080/00221686.2007.9521778.

Ben Mammou A., Louati, M. H. (2007) Temporal evolution of siltation of dams in Tunisia (Évolution temporelle de l'envasement des retenues de barrages de Tunisie), Rev. Sci. Eau, 20, 201-210, https://doi.org/10.7202/015813ar.

Carollo F. G., Ferro V., Termini D. (2005) Flow resistance law in channels with flexible submerged vegetation, Journal of Hydraulic Research, 131, 554-564, https://doi.org/10.1061/(asce)0733-9429(2005)131:7(554).

Dumas D. (2008) Erosion assessment of an alpine river: the Isère in Grenoble, France (Bilan d'érosion d'un cours d'eau alpin: l'Isère à Grenoble (France)), Z. Geomorphol., 52, 85-103, https://doi.org/10.1127/0372-8854/2008/0052-0085.

Fehri N. (2014) The worsening of the flood risk in Tunisia: Food for thought (L'aggravation $\mathrm{du}$ risque d'inondation en Tunisie: éléments de réflexion), Physio-Géo, 8, 149-175, https://doi.org/10.4000/physio-geo.3953.

Ghisalberti M., Nepf H. (2002) Mixing layers and coherent structures in vegetated aquatic flows, Water Resources Research, 34, 2341-2352, https://doi.org/10.1029/2001JC000871.

Hammami S. (2010) Hydrodynamique Fluviale de la Medjerda, Master of Hydrodynamics and Modeling of Coastal Environments, National Engineers School of Tunis, Tunisia.

Hardly R., Bates P., Anderson M. (1999) The importance of spatial resolution in hydraulic models for floodplain environments, Journal of Hydrology, 216, 124-136, https://doi.org/10.1016/s0022-1694(99)00002-5.

Horritta M., Batels P. (2002) Evaluation of 1D and 2D numerical models for predicting river flood inundation, Journal of Hydrology, 268, 87-99, https://doi.org/10.1016/s0022-1694(02)00121-x.

Huthoff F., Augustijn D. C. M., Hulscher M. H. (2007) Analytical solution of the depth-averaged flow velocity in case of submerged rigid cylindrical vegetation, Water Resource Research, 43, W06413: 1-10, https://doi.org/10.1029/2006WR005625.

Jarvela J. (2005) Effect of submerged flexible vegetation on flow structure and resistance, Journal of Hydrology, 307, 233-241, https://doi.org/10.1016/j.jhydrol.2004.10.013.

Jaziri B. (2009) The bio and the dam, riparian vegetation and hydraulic development (open water, constrained water), structure, functionality, representations in three rivers of northern Tunisia (Le bio et le barrage, végétation riveraine et aménagement hydraulique (eau libre, eau contrainte), structure, fonctionnalité, représentations dans trois cours d'eau de la Tunisie septentrionales), PhD Thesis in Physical Geography, Higher Normal School of Lyon, France.

Jourdain C. (2017) Flood action on sediment and plant dynamics in a pebble river bed: Isère en Combe de Savoie (Action des crues sur la dynamique sédimentaire et végétale dans un lit de rivière à galets: l'Isère en Combe de Savoie), PhD Thesis, University Grenoble Alpes. 
Klopstra D., Barneveld H. J., Van Noortwijik J. M., Van Velzen E. H. (1997) Analytical model for hydraulic roughness of submerged vegetation, Proceedings of the 27th Conference of the International Association for Hydraulic Research, San Francisco, New York, ISBN 90-77051-03-1: 775-780.

Kubrak E., Kubrak J., Rowinski P. M. (2008) Vertical velocity distributions through and above submerged flexible vegetation, Hydrological Sciences Journal, 53, 905-920, https://doi.org/10.1623/hysj.53.4.905.

Liu C., Shen Y. (2008) Flow structure and sediment transport with impacts of aquatic vegetation, Journal of Hydrodynamics, 20, 461-468, https://doi.org/10.1016/s1001-6058(08)60081-5.

Lopez F., Garcia M. H. (2002) Mean flow and turbulence structure of open channel flow through non-emergent vegetation, Journal of Hydraulic Engineering, 127, 392-402, https://doi.org/10.1061/(ASCE)0733-9429(2001)127:5(392).

Morri M., Soualmia A., Belleudy Ph. (2016) Mean Velocity Predictions in Vegetated Flows, Journal of Applied Fluid Mechanics, 9, 1273-1283, https://doi.org/10.18869/acadpub.jafm.68.228.24221.

Nepf H. (1999) Drag, turbulence, and diffusion in flow through emergent vegetation. Geophysical Union, Water Resources Research, 35, 479-489, https://doi.org/10.1029/1998wr900069.

Nepf H., Vivoni E. R. (2000) Flow structure in depth-limited, vegetated flow, Journal of Geophysical Research: Oceans, 105, 2547-2557, https://doi.org/10.1029/2000JC900145.

Righetti M., Armanini A. (2002) Flow resistance in open channel flows with sparsely distributed bushes, Journal of Hydrology, 269, 55-64, https://doi.org/10.1016/s0022-1694(02)00194-4.

Rodrigues S., Bréhéret J. G., Macaire J. J., Moatar F., Nistoran D., Jugé Ph. (2006) Flow and sediment dynamics in the vegetated secondary channels of an anabranching river: The Loire River (France), Sediment Geology, 186, 1089, https://doi.org/10.1016/j.sedgeo. .2005.11.011.

Samani J. M. V., Mazaheri M. (2009) An Analytical Model for Velocity Distribution in Transition Zone for Channel Flows over Inflexible Submerged Vegetation, Journal of Agricultural Science and Technology, 11, 573-584, http://journals.modares.ac.ir/article-23-6634-en.html.

Tsujimoto T., Okada T., Kitamura T. (1993) Turbulent flow over flexible vegetation covered bed in open channels, KHL progressive report 1, Kanazawa University, Kanazawa, Japan.

Van Rijn L. C. (1984) Sediment transport - Part I: Bed load - Part II: Suspended load, J. of Hydraulic Division, Proc. ASCE, 110, HY10, 1431-1456, HY11, 1613-1641.

Van Rijn L. C. (1993) Principles of Sediment Transport in Rivers, Estuaries and Coastal Seas, Aqua Publications.

Villaret V., Hervouet J. M. (2006) Cross-comparison of different approaches for sediment transport by bed load and suspension, Ninth National Days Civil Engineering - Coastal Engineering, National Laboratory of Hydraulics and Environment, 12-14 September 2006, Brest, France, 463-470.

Villaret V., Hervouet J. M., Kopmann R., Merkel U., Davies A. G. (2013) Morphodynamic modeling using the Telemac finite-element system, Computers \& Geosciences, 53, 105-113, https://doi.org/10.1016/j.cageo.2011.10.004.

Wu W., He Z. (2009) Effects of vegetation on flow conveyance and sediment transport capacity, International Journal of Sediment Research, 24, 247-259, https://doi.org/10.1016/S1001-6279(10)60001-7.

Zahar Y., Ghorbel A., Albergel J. (2008) Impacts of large dams on downstream flow conditions of rivers: Aggradation and reduction of the Medjerda channel capacity downstream of the Sidi Salem dam (Tunisia), Journal of Hydrolology, 351, 318-330, https://doi.org/10.1016/j.jhydrol.2007.12.019. 